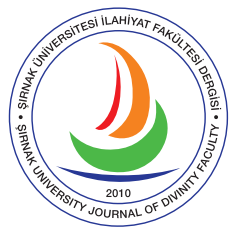

e-ISSN 2667-6575

\title{
İslam Edebiyatında İlmin Adabına Dair Bir Değerlendirme
}

An Evaluation on Adab of Science in Islamic Literature

\section{Murat Ataman}

Araştırma Görevlisi, Bursa Uludağ Üniversitesi, İlahiyat Fakültesi,

Arap Dili ve Edebiyatı Ana Bilim Dalı

Research Assistant, Bursa Uludağ University, Faculty of Theology, Departmant of Arabic Langauge and Rhetoric

Bursa, Turkey.

murat-ataman58@hotmail.com

https://orcid.org/0000-0002-7049-3125

\section{Adnan Arslan}

Doç. Dr., Bilecik Şeyh Edebali Üniversitesi, İslami İlimler Fakültesi,

Arap Dili ve Belagatı Ana Bilim Dalı

Associated Professor, Bilecik Şeyh Edebali University, Faculty of Islamic Sciences, Departmant of

Arabic Langauge and Rhetoric

adnan.arslan@bilecik.edu.tr

https://orcid.org/0000-0002-3989-6612

\section{Makale Bilgisi / Article Information}

Makale Türü / Article Types: Araştırma Makalesi / Research Article

Geliş Tarihi / Received: 30 Mart / March 2020

Kabul Tarihi / Accepted: 6 Mayıs / May 2020

Yayın Tarihi / Published: 15 Haziran / June 2020

Cilt / Volume: 11 Sayı / Issue: 24 Sayfa / Pages: 346-367

Atıf / Cite as: Ataman, Murat - Arslan, Adnan. "İslam Edebiyatında İlmin Adabına Dair Bir Değerlendirme [An Evaluation on Adab of Science in Islamic Literature]". Şırnak Üniversitesi İlahiyat Fakültesi Dergisi-Şırnak University Journal of Divinity Faculty 11/24 (June 2020), 346-367. https://doi.org/10.35415/sirnakifd.711548

Etik Beyanı / Ethics Declaration: Bu makalede bilimsel araştırma ve yayın etiği ilkelerine riayet edilmiştir. Makale etik izin gerektirmeyen bir çalışma olup en az iki hakem tarafından incelenmiş ve intihal içermediği teyit edilmiştir./ In this article, the principles of scientific research and publication ethics are respected. The article is a study that does not require ethical permission. It has been reviewed by at least two referees and was confirmed that it did not contain plagiarism. Copyright (C) Published by Şırnak Üniversitesi, İlahiyat Fakültesi / Şırnak, Türkiye (Şırnak University, Faculty of Divinity, Şırnak, 73000 Turkey). 


\title{
Öz
}

Doğru davranışın ancak doğru bilgiden kaynaklanabileceği gerçeğinden hareketle, doğru davranışları hedefleyen İslam dininde, ilmin tahsiline son derece önem verilmiştir. Bu önem, İslam edebiyatında "ilim" konulu sayılamayacak nicelikte eserin vücuda gelmesinde kendini göstermektedir. Yine bu öneme binaen hadis ve Arap edebiyatı kaynaklarına baktığımızda ilim tahsilinde bulunacak öğrencilerin takınması gereken özel bir "ilim âdâbı" alanının oluştuğu görülmektedir. Aslına bakılırsa ilim öğrenmek her Müslüman'a farzdır. Ancak bu tür "ilim âdâbı" eserlerinde birinci derecede hedef kitle, hayatının bir kısmını ilme tahsis etmiş "talebe" kesimidir. İlim taliplisinin bir ömür boyu sürecek tahsil yolculuğunda kritik eşikler, savrulmaya müsait dönemeçler ve ilmin istismara uğrayabileceği riskli alanlara dair pek çok ikaz ve işaretler bu eserlerde bulunmaktadir. Zira kimi zaman ilmi bir yanlış ameli pek çok doğruya mal olabilmektedir. Bu çalışmada, ülkemizde İslami ilimler tahsili ile meşgul olan önemli sayıda bir kesime ve bu kesim içerisinde de özellikle "yeni başlayanlara" yönelik hadis ve Arap edebiyatı kaynaklarından derlenmiş prensipler ele alınmıştır. Çalışma ağırlıklı olarak sunum ve değerlendirmeye dayalı olacağı için konu çerçevesinde -rehberlik amaçl1- seçilen literal malzeme arz edilerek günümüz -İslami ilimler öğrencilerine- göre yorumlanmıştır.

Anahtar Kelimeler: Arap Dili ve Belâgatı, Hadis, İlim, Âdâb, İslami İlimler.

\begin{abstract}
Considering the fact that the right behavior can only arise from the right information, the education of science has been given utmost importance in the Islamic religion aiming at the right behaviors. This importance manifests itself in the inclusion of an unquestionable quantity of "science" in the Islamic literature. When we look at the hadith and the sources of Arabic literature due to this importance, it is seen that there is a special field of scholars of science that should be attached to the students who will study science. In fact, it is obligatory for every Muslim to learn science. However, the first degree of target audience in such works of "science ethic" is the "student" segment that has devoted part of its life to science. Critical thresholds, bendable bends and risky areas where science can be exploited are found in these works. Because sometimes a scientific mistake can cost many truths. In this study, the principles compiled from the sources of hadith and Arabic literature for a significant number of people engaged in the collection of Islamic sciences in our country and especially for the "beginners" were compiled. Since the study will be mainly based on presentation and evaluation, the selected material will be presented within the framework of the subject - for guidance purposes - and will be interpreted according to the present - Islamic sciences students
\end{abstract}

Keywords: Arabic Language and Rhetoric, Hadith, Science, Ethics, Islamic Sciences. 


\section{Extended Abstract}

In many verses and hadiths, the virtue of science has been expressed in different ways. When we look at the classical literature sources that we can call a kind of culture collection for Muslims it is seen that the science is among the prioritized topics. Various materials, phrases, anecdotes etc. has been emphasized on the value of science for a long time. Literary sources are important in terms of reflecting Muslim society's view of science. In this article the recommendations for science students have been brought together in religious and literary texts. In summary what is said in the context of scientific advice is as follows: First of all it is emphasized in the literary books that the value that makes human beings real is "knowledge". If a person lacks science, it is not worth having a supreme lineage or being in a high position. For this reason, it has been advised that it is wrong to admire the fact that people favor their owners and owners. Because in the event that the property and its location disappear, the traits of none of these favors are read, all of them disappear. In every period, goods and properties have been at the top of what people love most and consume their lives to earn them. For this reason, when the value of science is tried to be explained, references to the property and property are generally made. Although it is a great value to have knowledge, it has always been a matter of interest when the power and value of the power are not known enough. An important reason for this is that the scientists themselves do not know the value of the science they carry, they exhibit behaviors and behaviors that do not suit them and are a bad example to people. Intention is a powerful motive that directs people in terms of affecting the work done. It is indisputable that there is a big difference between a student trying to pass an exam and a student who wants to apply what he has learned in his life. Therefore, the intention to learn should be primarily to eliminate one's own ignorance. When this happens, the knowledge learned will be internalized and will shape the life of man. Otherwise, an unwillingness towards science will emerge, considering that what is learned after a while does not make sense. Sometimes the student's enthusiasm for knowledge is broken when he is at the beginning of the road. When it is examined, it is understood that it is a situation related to falling down. Often, an inaccessible science and scholar portrait is drawn to encourage the so-called student. He sees the scientific position shown as the target and the profile of the scientist as inaccessible to the demand evaluating himself and his conditions; As a result, his enthusiasm for knowledge is broken. However, it must first be to target the minimum level of knowledge. In this regard, it is stated in the literary books that some philosophers say: My goal in science demand is not to reach the last point in science; my aim is to get the amount that ignorance cannot be excused. Although learning is 
said to have no age, learning at a young age is compared to "embedding" in knowledge, and learning at an advanced age is compared to "trying to embroider" in water. It is stated that the virtues that the science demand should adopt should be a good listener at the very beginning. Being a listener in the course rings was seen as a superior merit than speaking. Because choosing to listen to speaking first of all implies that one's mind; The way to have a strong science is only to be a good listener. It can be said that one of the most dangerous diseases transmitted to human beings in the duration of the demand for science is taassup. However, science is first and foremost a search for truth. Truth is not something that can be measured by religion, language, race, and piety. It can be said that one of the most important obstacles to scientific success is the way it works beautifully / systematically. For example, leaving it half while busy with another job, or doing it halfway with another job is some of them. Man of letters stated that this type of work would not only disrupt scientific success. It can be said that there are many factors that push the science student to work without a system. At the beginning of these, not knowing where and how to start, not being able to predict which science you want to deepen. Numerous information will emerge that the science student will encounter during his collectible life. There is no need to even explain the impossibility of having knowledge of all of this information. So what the ingenious traveler doing with science knows is that he knows how to act "selectively" about this information. Because the science square is as wide as possible and the roads to go are too many to count. Poetry, which is the divan of Arabs, contains whatever cultural, religious and moral belongs to Arab and has been passed down from generation to generation as a strong cultural heritage. One of the moral virtues in this heritage is to know how to keep quiet where it is needed. The wise silence, praised in the Qur'an and Sunnah, was seen as a requirement of the literary and devoted and also became an indicator of one's social reputation. This meaningful silence has been the subject of poetry in Arabic poetry since the first period. One of the problems encountered in science education is that the demand is sometimes dealing with complex issues. Although such issues sometimes increase the enthusiasm for learning by attracting the interest and curiosity of the demand, it often confuses and gives a coldness and demoralization to deal with science. Human beings are hostile to what they do not know by their nature and tend to the subjects they can understand. Here, it is important to ask questions beautifully if needed. As a result, it is possible to say the following: It is emphasized that the demand that wants to engage in the science in general in Islam literature should keep his intention towards the knowledge sincere from the beginning and be always excited about what the purpose of knowledge is. 


\section{GíRiş}

Âlimler ilmi, "bir şeyin hakikatini idrak etmek" olarak tarif etmişlerdir. ${ }^{1}$ İlim maluma tabidir. Dolayısıyla her ilmin (bilmek) değeri, malumun (bilinen) değerine göre belirlenir. ${ }^{2} \mathrm{Bu}$ açıdan bakıldığında ilimler arasında İslami ilimlerin ayrı bir yeri vardır. Çünkü İslami ilimler insana en yüce olanı (Allah'ı) tanıtır ve varlık gayesini öğretir. Böylelikle insanoğlu dünyada ve ahirette saadete kavuşmanın yollarını öğrenmiş olur.

Birçok ayet ve hadiste ilmin fazileti değişik biçimlerde dile getirilmiştir. ${ }^{3}$ Müslümanlar için bir tür kültür koleksiyonu diyebileceğimiz klasik edebiyat kaynaklarına bakıldığında ise ilim bahsinin öncelik verilen konular arasında yer aldığg görülür. Çeşitli materyaller, vecizeler, anekdotlar, darbı meseller vs. kullanılarak ilmin kıymeti üzerinde uzun uzadıya durulmuştur. Bunun nedeni edebiyatın insana yüce bir kimlik kazandırma gayreti içerisinde olmasıdır. ${ }^{4}$ Keza Müslüman toplumların ilme bakışını yansitıyor olması bakımından önem arz etmektedir.

Her şeyden önce $e d e b$ kitaplarında insanı gerçek manada insan yapan değerin "ilim" olduğu üzerinde durulmuştur. Bir kimse ilimden yoksunsa yüce bir soya sahip olmasının veya yüksek bir mevkide bulunmasının kıy-

${ }^{1}$ Ebü'1-Kāsım Hüseyn b. Muhammed b. el-Mufaddal Râgıp el-İsfehânî, el-Müfredât fî garîbil-Ku'rân, thk. Saffân Adnân ed-Dâvûdî (Dimeşk: Dârüll-kalem, 1991), 580; Ali b. MuhammedSeyyid Şerîf el-Cürcânî, Kitâbü't-Ta'rîfât, thk. Muhammed es-Siddîk el-Minşâvî (Kâhire: Dârü'l- Fazîle, 2004), 130.

2 Ebü'l-Kāsım Mahmûd b. Ömer b. Muhammed el-Hârizmî Zemahşerî, el-Keşşâf an hakâiki ğavâmidi't-tenzîl (Beyrut: Dâru'l-kitâbi'l-arabî 1987), 4/819.

3 İlmin fazileti ile ilgili bk. Ebû Ömer Cemâlüddîn Yûsuf b. Abdillâh b. Muhammed enNemerî İbn Abdilberr,Câmiu beyânil-ilm ve fazlihî, thk. Ebi'l-Eşbâl ez-Züheyrî (ed-Dammam: Dârü ibni'l-Cevzî, 1994).

4 M. Kaya Bilgegil, Edebiyat Bilgi ve Teorileri (Erzurum: Salkımsöğüt Yayınevi, 2015), 16-21. 
meti yoktur. ${ }^{5}$ Çünkü "gücünü ilimden almayan şan ve şeref sonunda zelil olmaya mahkûm" görülmüştür. ${ }^{6}$ Bu nedenle insanların mülk ve mevki sahiplerine teveccüh ediyor olmasına hayranlık duyulmasının yanlış olduğu öğütlenmiştir. Zira mülk ve mevkiinin yok olması durumunda bu teveccühlerin hiçbirinin esamesi okunmaz, hepsi yok olup gider. Fakat yapılan teşrif ve ikramlar o kimsenin sahip olduğu ilim ve irfandan kaynaklanıyorsa bu durumda hayran olmakta bir beis yoktur. ${ }^{7}$

İlimden mahrum olmak talihsizliğin en kötüsü olarak görülmüştür. Çünkü bu durum aynı zamanda Allah'ın o kimseye değer vermediğinin alameti olarak değerlendirilmiştir. ${ }^{8}$ Tam tersini söylemek de mümkündür; bir kimseye ilim verilmiş olması o kimsenin Allah katında ki değerinin/ kıymetinin en önemli göstergesidir. ${ }^{9}$

Bu çalışmada, ilmin ehemmiyetine ve ilim talebesinin kutlu yolculuğunda dikkat etmesi gerektiği hususlara işaret eden edebi değerlendirmelere müstakil başlıklar halinde değinilecektir.

\section{1. İLMINN ÖNEMİ}

İlmin kadir ve kıymetini anlatan en güzel sözlerden biri Cüneyd elBağdadi'nin (öl. 297/909) Kur'ân-1 Kerim'den yaptığı şu istidlaldir: İlmin dünya metaına olan üstünlüğünü bilmek istersen Allah Teâlâ'nın Hz. Süleyman'a tek bir mesele öğrettikten sonra onu minnet altında bıraktığ1 şu ayete bakabilirsin: "Her birine hüküm ve ilim verdik."10 Diğer taraftan hiçbir beşere verilmemiş olan mal ve mülkü Allah Teâlâ kendisine vermiş olmasına rağmen bu hususta onu minnet altında bırakmamış; hatta şöyle

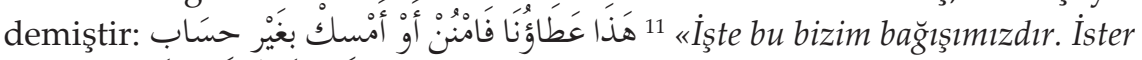
ver, ister (elindé) tut; hésapsizdır» dedik. ${ }^{12}$

Her dönemde mal ve mülk, insanın en çok sevdiği ve ömrünü bunları kazanmak için tükettiği şeylerin başında yer almıştır. Bu nedenle ilimin kıymeti anlatılmaya çalışıldığında genelde mala ve mülke olan üstünlü-

5 Râgıb el-İsfehânî, Muhâdarâtü'l-üdebâ (Beyrut: Dârü'l-Erkam b. Ebi'l-Erkam,1999), 1/48.

6 Râgib el-İsfehânî, Muhâdarâtü'l-üdebâ, 1/48.

7 Ebû Muhammed Abdullâh b. Müslim İbn Kuteybe, 'Uyûnu'-ahbâr (Beyrut: Dâ-ru'l-kütübi'lilmiyye, 1997), 2/137

8 Ebû Hayyân el-Endelusî Tevhîdî, el-Basâir ve'z-zehâir, thk. Vedâd el-Kâdî (Beyrut:Dârü Sâdir, 1988), 7/43

9 Ebû Abdillah Muhammed b. İsmâil Buhârî, Sahîhu 7-Buhârî, thk. Muhammed Zuheyr b. Nâsirinnâsir (b.y. Dârü tavki'n neccât, 1422), 1/24.

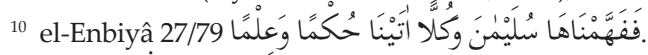

${ }^{11}$ Râgib el-İsfehânî, Ḿuhâdarâtül-üdebâ, 1/49.

12 Sâd 38/39. 
gü̈ne atıflar yapılmıştır. Mesela sultanlık herkesçe çok yüce bir mevki olarak kabul edilmesine rağmen ilmin-ilim sahibi olmanın çok daha yüce bir mevki olduğu çeşitli şekillerde dile getirilmiştir. Meşhur dil âlimi Ebü'l Esved ed-Düelî (ö. 69/688) bunu şu veciz sözüyle dile getirmiştir:

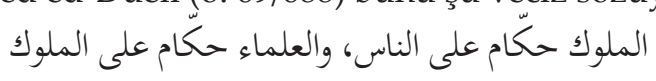

Sultanlar insanların hükümdarıdır. Âlimler ise sultanlara hükümdardır.

Keza edeb kaynaklarında Harun Reşid ile imam Malik arasında geçtiği rivayet edilen şu kıssada ilmin yüceliğini çarpıcı bir şekilde ortaya koymaktadır:

Bir gün Halife Harun Reşid adamlarını imam Malik'in yanına göndererek huzuruna gelip hadis okumasını emreder. İmam Malik ise gelen adamlara halifeye "ilmin ayağına gelinir; ilim kimsenin ayağına gitmez." sözünün iletilmesini ister. Bunun üzerine Harun Reşid İmam Malik'in huzuruna gelir ve sırtını duvara yaslayarak oturur. (Bu şekilde oturulmasindan hoşlanmayan) İmam Malik bu kez şöyle der: Ey müminlerin emri, (bilesin ki) ilmi yüceltmek Allah'ı yüceltmektir. Harun Reşid derhal kalkar ve İmam Malikin önünde diz çöker ve hadis dinler. ${ }^{13}$

İlim sahibi olmak çok büyük bir değer olmasına rağmen kadir ve kıymetinin yeterince bilinmediği her dönemde mevzu bahis olmuştur. Bunun iki önemli nedeni vardır. Birincisi: İlim ehlinin bizatihi kendilerinin, taşıdıkları ilmin değerini bilmemeleri, kendilerine yakışmayan hal ve davranışlar sergileyip insanlara kötü örnek olmalarıdır. ${ }^{14} \mathrm{Bu}$ durumdan oldukça muzdarip olan Fudayl b. İyâz (ö.187/803) şöyle serzenişte bulunmuştur: Âlimler halkın gönlünde bahar mevsimi gibiydiler. Hastalar onlarla birlikte olduğunda iyileşmeyi istemezlerdi. (Allaha kavuşma arzusundan) Fakirler onlar gördüklerinde zenginliği arzu etmezlerdi. (Yaşadıkları örnek züht hayatı nedeniyle) Oysa şimdi sözüm ona ilim erbabı, insanlara fitne oldular. ${ }^{15}$ Oldukça örnek bir kişiliğe sahip olan meşhur dil üstadı Halîl b. Ahmed el-Ferâhîdî (ö.175/791) bazı davranışlarının etrafındakilere fitne olabileceğinden çekindiği için, kendisinden alınması gereken yegâne şeyin ilim olduğunu

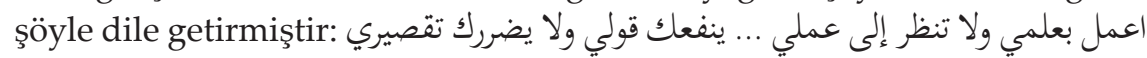
(Benden ilmimi al, yaptıklarıma ise aldırış etme. (Böyle yaparsan) Sözlerim işine yarar, davranışlarım zarar vermez sana.) İkincisi: Mum dibine ışı1k vermez misali, bulundukları muhit ve çevrenin kendilerine aşina olmaları hasebiy-

\footnotetext{
${ }^{13}$ Râgib el-İsfehânî,Muhâdarâtü l-üdebâ, 1/52.

14 İbn 'Abdirabbih,Ebû Ömer Şihâbüddîn Ahmed b. Muhammed b. Abdirabbih b. Habîb el'Ikdül-ferîd, thk. Müfîd Muhammed Kumeyha (Beyrut: Dârü'l-kütübi'l-ilmiyye, 1983), 2/89.

15 İbn 'Abdirabbih, el-'Ikdü'l-ferîd, 2/93.
} 
le insanların gözünde sıradanlaşarak basite alınmalarıdır. Peygamberler dahi bu duruma maruz kalmışlardır.

Edeb kitaplarında anlatılana göre İncil'de konuyla alakalı şöyle bir anekdot yer alır: Hz. İsa (a.s.) insanlara mucizeler gösterip onlara hikmet dolu sözler öğretince bir zaman sonra şöyle demeye başladılar: Ya bu (Hz. İsa) bizim marangozun oğlu değil mi?! Annesi Meryem, kardeşi Yakup, Yusuf, Şem'un ve Yehuza. Bunların hepsi bizim içimizden olan tanıdığımız bildiğimiz kimseler! Bu söz üzerine Hz. İsa (a.s.) onlara hitaben şöyle dedi: Bir peygambere ancak yaşadığı şehrindeki hemşerileri söver ve onu küçük görür. ${ }^{16}$

Hatta bu münasebetle İmam-1 Şâfiî (ö. 204/820) ilimle iştigal eden kimselerin bir yerde uzun süre kalmasını doğru bulmamıştır. Farklı coğrafyalar, yeni kültürler, değişik algı ve anlayışlar ilim erbabının ufkunu açan ve onun genişlik ve derinliğini artıran şeylerdir. Şair hayatına yansıttığı bu düşüncelerini şiir formunda aktarmak istediğinde zımni/kapalı bir teşbihle şöyle söylemiştir:
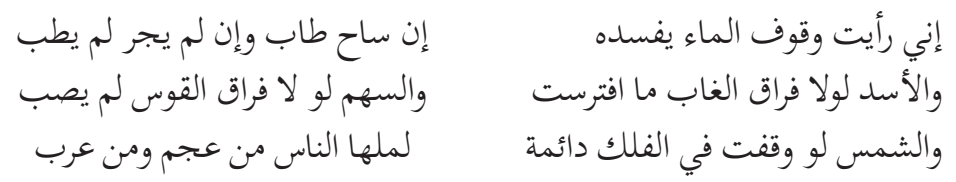

Görüyorum ki suyun duruşu onun tadını bozmaktadır.

Akarsa güzel olur akmazsa kötü.

Aslanlar ormandan ayrllirsa avlanır.

Ok yaydan ayrulmazsa hedefini vuramaz da.

Güneş eğer sürekli gökyüzünde sabit dursa

Arap acem herkes ondan sikılır. ${ }^{17}$

\section{2. İLIM TAHSİLİNDE GENEL İLKELER}

Niyet, yapılan işlere tesir etmesi bakımından insana yön veren güçlü bir saiktir. Sınav geçmek için çalışan bir talebeyle, öğrendiklerini hayatında uygulamak isteyen bir öğrencinin ilimden elde edeceği fayda arasında büyük fark olduğu tartışılmazdır. Bu manada ilim talebesinin nasıl bir maksat içerisinde olması gerektiğini Amr b. Dînâr (ö.126/744 ) şöyle ifade etmiştir: İnsan, ilmi kendisi için öğrenecekse az bir ilim ona yeter; yok insanlar

\footnotetext{
${ }_{16}$ İbn Kuteybe, 'Uyûnu'l-ahbâr, 2/134.

17 Muhammed b. İdrîs eş-Şâfiî,Dîvânu'l-İmâmi'ş-Şâfiì, nşr. Muhammed İbrâhîm Selîm(Kahire: Mektebetu İbn Sînâ, ts.), 26.
} 
için öğrenecekse insanların ihtiyacı hiç bitmez. ${ }^{18}$ Dolayısıyla öğrenme niyeti öncelikle insanın kendi cehaletini gidermek için olmalıdır. Böyle olduğunda öğrenilen bilgi içselleştirilecek ve insanın hayatına yön verecektir. Aksi takdirde bir zaman sonra öğrenilen şeylerin bir anlam ifade etmediği düşünülerek ilme karşı bir isteksizlik baş gösterecektir. ${ }^{19} \mathrm{Bu}$ durum tıpkı savaş hazırlığında olan birinin durmadan silah yığıp ama bir türlü savaşa gitmemesine benzetilebilir. Silahlar nasıl ki savaş için bir araç ise ilimde amel etmek için bir araçtır denilmiştir ${ }^{20}$

Kimi zaman da daha yolun başındayken öğrencinin ilme olan hevesi kırılır. Bunun nedeni tetkik edildiğinde ye'se düşmekle alakalı bir durum olduğu anlaşılır. Çoğu zaman sözüm ona talebeyi teşvik etmek için ulaş1lmaz bir ilim ve ilim adamı portresi çizilir. Kendini ve şartlarını değerlendiren talebe, hedef olarak gösterilen ilmi konumu ve ilim adamı profilini ulaşılmaz olarak görür; neticede ilme karşı olan hevesi kırılır. Oysa olması gereken önce, asgari seviyedeki ilim seviyesini hedef göstermektir. Bu hususta edeb kitaplarında bazı filozofların şöyle dediği nakledilmiştir: İlim talebindeki gayem ilimde son noktaya ulaşmak değildir; gayem cehaleti mazur görülmeyecek olan miktarn elde etmektir. ${ }^{21}$

Öğrenmenin yaşı başı yoktur denilmiş olsa da küçük yaşta öğrenmek bilginin " taşa nakşedilmesine", ileri yaşlarda öğrenmek ise bilginin "suya nakşedilmeye çalışılmasına" benzetilmiştir. ${ }^{22}$ Benzer bir söze kulak misafiri olan Ahnef b. Kays (ö. 67/686-87) bunun nedeni -aslında ileri yaşta olan bir kimsenin akılca küçük yaşta olandan çok daha güçlü olmasına rağmenhayat meşgalesinin öğrenilen bilginin kalıcılığını zayıflattığına bağlamıştır. ${ }^{23}$ Keza İmam Şâfiî erken yaşta ilim yapmanın önemini şu dizeleriyle dile getirmiştir:

$$
\begin{gathered}
\text { ومن فاته التعليم حال شبابه فكبر عليه أربعا لوفاته } \\
\text { Gençliğinde elde edememişse ilim } \\
\text { O vakit dört tekbir getir sen ona vefatı dolayısıyla. }
\end{gathered}
$$

Fakat hemen şunu da belirtmek gerekir ki yaş geçti diye cahil kalmaya razı olmak bir başka cehalet örneğidir. Abbasi Halifesi Me'mûn’la (ö.

\footnotetext{
${ }_{18}$ İbn Kuteybe, 'Uyûnu'-ahbâr, 2/142.

19 Tevhîdî, el-Basâir ve'z-zehâir, 5/177.

${ }^{20}$ Ebû Mansûr Se'âlibî, ş-Şekvâ ve'-'itâb ve ma vaka'a beyne'-hillân vel-eshâb, thk. İlhâm Abdülfettah el-Müftî (Kuveyt: el-Meclisü'l-vatanî li's-sekâfe ve'1-fünûn, 2000), 222.

${ }^{21}$ İbn 'Abdirabbih, el-'Ikdül-ferîd, 2/77.

22 İbn Kuteybe, 'Uyûnu'-ahbâr, 2/139.

${ }^{23}$ Ebû Osman 'Amr b. Bahr Câhiz, Kitâbül-mehâsin ve'l-azdâd (Beyrut: Mektebetü'l-Hilâl, 2004), 30.
} 
218/833) bir akrabası arasında geçen konuşma bu manada güzel bir öğüt içermektedir: Halife Me'mûn'a yaşını başını almış bir akrabası sorar: Ey hünkârım! Benim bu yaşta ilim talep etmem uygun düşer mi sizce? Me'mûn şöyle cevap verir: Elbette! İlim talebesi olarak son nefesini vermen cehalete razı gelmiş biri olarak ölmenden yeğdir. ${ }^{24}$

İlim talebesinin prensip edinmesi gereken meziyetlerin en başında iyi bir dinleyici olması gerektiği belirtilmiştir. Ders halkalarında dinleyici olmak, konuşan olmaktan çok daha üstün bir meziyet olarak görülmüştür. ${ }^{25}$ Çünkü dinlemeyi konuşmaya tercih etmek her şeyden önce o kimsenin aklına delalet etmektedir; güçlü bir ilme sahip olmanın yolu da ancak iyi bir dinleyici olmaktan geçmektedir. ${ }^{26}$

Bir kimse eğer dinlemeyi bilmiyorsa fehimi güçlü olsa bile ilim öğrenimi için uygun görülmemiştir. Âlimlerin böyle kimselere ilim öğretmekten geri durdukları dahi olmuştur. Bunun nedeni dinlemeyi bilmemenin ilim ahlakıyla bağdaşmaması olabileceği gibi meselelerin kötü ezberlenmesine yol açması da olabilir. Birazdan nakledeceğimiz anektot anlatılanı beyan eder mahiyettedir:

Abbasi şairlerinden Ebû Yâkûb el-Hureymî'nin (ö. 214/829) naklettiği bir hadise konuyla alakalı olarak örnek gösterilebilir. Başından geçen olayı Hureymî şöyle anlatır: Gün doğumundan sonra yolda Said b. Vehb ile karşılaştım. (Hayrola dostum) Nereye böyle, diye sordum? Said: Peygamberin bir hadisini işitirim diye (meclisleri) dolaşıyordum. Daha sonra yolda Enes $b$. Eb̂̂ Şeyh (ö.?) ile karşılaştım ve nereye gidiyorsun diye sordum. O "Ezberimde bir hadis var; onu nakletmek için anlayışı güçlü dinlemeyi beceren birini arıyorum" dedi. Bunun üzerine ben, "hadi onu bana naklet", dedim. Enes: Evet doğru, sen anlayışı güçlü birisin; ama maalesef çok kötü bir dinleyicisin. O yüzden onu sana aktaramam, dedi. ${ }^{27}$

İlim talebi süresinde insana bulaşan en tehlikeli hastalıklardan birinin taassup olduğu söylenebilir. Oysa ilim her şeyden önce bir hakikat arayışıdır. Hakikat ise din, dil, ırk, takva ile ölçülebilecek bir şey değildir. İlk dönem hadisçilerinden Eyyûb es-Sahtiyânî'nin (ö. 131/749) sergilediği şu davranış bu hususta güzel bir örnektir: İlim erbabı arasında öyle tanıdıklarım var $k i$ dualarının Allah katında makbul olduğunu hüsnü zan ederim. Ne var ki bana bir

${ }^{24}$ Ebü't-Tayyib Veşşâ, ez-Zarf ve'z-zurefâ, thk. Kemal Mustafa (Kâhire: Mektebetü'1Hancî,1953), 12.

25 İbn Kuteybe, 'Uyûnul-ahbâr, 2/137.

${ }^{26}$ Câhiz, Kitâbü '-mehâsin vel-azdâd, 42.

27 İbn Kuteybe, 'Uyûnul-ahbâr, 2/144. 
hadis rivayet edecek olsa bunu katiyen kabul etmem. ${ }^{28}$ Dolayısıyla ilme bakışı açısı edeb kitaplarında yer alan "hikmet (hakikat) müminin yitik malıdır; şirk ehlinden de olsa onu öğrenin." sözünde olduğu gibi olmalıdır. ${ }^{29}$ Taassuptan uzak olmanın formülü ise farklı hocalardan ders almaktan geçmektedir. Öyle ki insan böylelikle hocalarını yanlışların görebilir ve onlardan birine taassup etmekten uzak kalabilir. ${ }^{30}$

İlmi başarının önündeki en önemli engellerden biri de gelişi güzel/sistemsiz çalışma biçimidir denilebilir. Örneğin bir işle meşgulken onu yarım bırakıp başka bir işle meşgul olmak veyahut yapılan işi yarım yamalak yapmak bunlardan bazılarıdır. Edipler bu türden bir çalışma tarzının yalnızca ilmi başarıyı sekteye uğratmakla kalmayacağını, aynı zamanda insanın anlayışına da zarar vereceğini ifade etmişlerdir. ${ }^{31}$ Her ne olursa olsun yapılan işin layıkıyla yapılması başarıya giden yolda oldukça önemli bir prensiptir. Bu manada peygamberden rivayet edilen bir hadis dikkat çekicidir: Allah'ın resulü oğlu İbrahim'in mezarındaki bir kerpiçte yarık görür ve bunun derhal düzeltilmesini ister. Ardından da şöyle der: Evet, bu yarığın olmasının (ölü için) hiçbir zararı ve faydası yoktur. Fakat Allah, kulunun bir işi düzgün yapmasını sever. ${ }^{32}$

İlim talebesini sistemsiz çalışmaya iten birçok faktörün olduğu söylenebilir. Bunların en başında ise nereden ve nasıl başlanması gerektiğini bilmemek, hangi ilimde derinleşmek istediğini kestirememek gösterilebilir. İbn Sîrîn'e göre (ö. 110/729) öncelikli olarak yapılması gereken her ilimden en temel bilgiyi elde etmektir. ${ }^{33}$ Sonrasında ise önem sırasına göre bir cetvel takip edilmelidir. Her şeyden önce farz olan ilimlere öncelik verilmelidir. ${ }^{34}$ Sonrasında ise insan en çok merak ettiğine, hoşlandığına ve kolay gördüğüne yönelmelidir. İlmi derinliğin ancak bu şartlar yerine geldiğinde gerçekleşebileceği söylenmiştir. ${ }^{35}$

İlim tahsilinde karşılaşılan sorunlardan biri de ezberin mi yoksa fehm (anlamanın) mı öncelenmesi gerektiğidir. Çağımızda eğitim ve öğretim alanında ezberciliğin ciddi manada tenkit edildiği bilinen bir gerçektir. Çok yönlü bir ilim adamı olan Câhız bu sorunu şöyle değerlendirmiştir: Önde gelen filozoflar ve fikir adamlar ezberciliği kötü görmüşlerdir. Zira onlara göre ezbercilik akl ihmal etmek olup ezberlenen şeye dayanıp güvenmektir. Bu nedenle şöy-

\footnotetext{
${ }_{28}$ İbn 'Abdirabbih, el-'Ikdü'l-ferîd, 2/85

29 İbn Kuteybe, 'Uyûnu'l-ahbâr, 2/139.

30 İbn 'Abdirabbih, el-'Ikdü l-ferîd, 7/295.

${ }^{31}$ İbn Kuteybe, 'Uyûnu'l-ahbâr, 2/183

32 Ahmed b. Hanbel, Müsnedül-İmam Ahmed b. Hanbel, thk. Şu'ayb el-Arnâût (Beyrut: Müessesetü'r-Risâle, 2001), 36/524; Ebû Mansûr es-Se'âlibî, eş-Şekvâ ve'l-'itâb, 224.

33 İbn 'Abdirabbih, el-'Ikdül-ferîd, 1/5.

34 İbn 'Abdirabbih, el-'Ikdül-ferîd, 2/77.

35 İbn 'Abdirabbih, el-'Ikdü'l-ferîd, 2/81.
} 
le demişlerdir: الحفظ عذق الذّهن lezber zihni budamaktır. Bir diğer neden ise ezberin aslında bir taklitten ibaret olmasıdır. Oysa düşünce neticesinde yapılan çıarımlar insanı hakikate ve güvenilir bilgiye götürür. Ancak doğru ve isabetli olan şudur ki uzun süre ezberle meşgul olmak meselelerden çıkarım yapma işini zayıflatır. Sürekli çıkarım yapmak ise ezber kabiliyetine zarar verir. Bununla birlikte ezberin akli çıkarımlar yapmaktan daha değerli olduğunun altın çizmek gerekir. Düşünce ihmal edildiğinde anlamin yakalanması yavaşlar. Ezber ihmal edildiğinde ise anlam kalpte kahıı olmaz. Her ikisinin de iyi bir şekilde yapılabilmesi ise şu iki şeyle mümkündür: Kalpten meşguliyetlerin atılması ve şiddetli bir şekilde arzulamak. ${ }^{36}$

\section{BİLMIYYORUM DİYEBİLMENİN ÖNEMİ}

Melekler, Allah'ın "Bunların isimlerini bana söyleyin." ${ }^{37}$ hitabına karşın; "Senin bize öğrettiğinden başka ilmimiz yok." ${ }^{38}$ diyerek cevap vermişlerdir. Allah ile melaike arasında geçen bu mükâleme, bir bakıma bilgimiz olmayan konularda "bilmiyorum" diyebilmenin "melaike" ye yaraşır bir ahlak olduğunu göstermektedir. Bunu teyit eden bir rivayete göre, bir adam Allah Rasûlü'nün (s.a.v.) yanına gelerek; "En hayırlı yerler nerelerdir?" ve "En şerli yerler nerelerdir?" şeklinde iki soru sormuştur. Hz. Muhammed (s.a.v.) bu iki sorunun ikisine de لا أدري "Bilmiyorum." diyerek cevap vermiş̧tir. Hadisin devamına göre aynı sorulara Cebrail de (a.s.) "Bilmiyorum." cevabını vermiştir. Sonrasında ise bizzat Allah bu soruları cevaplandırmış ve "Yeryüzünde en hayırlı yerler mescitler; en şerli olanları ise çarşılardır." buyurmuştur.

Hz. Peygamber'in (s.a.v..) bilmediği konularda لا أدري dediğine dair başka rivayetler de bulunmaktadır. Bir keresinde "Bilmiyorum Tubba' melun muydu değil miydi? Zülkarneyn peygamber miydi?; cezalar günahlara kefaret olur mu? Bunları bilmiyorum." Hz. Peygamber (s.a.v.) dahi bilgisi olmadığı konularda tekellüfe girmez; ya sükût eder ya da "bilmiyorum" diyerek Allah'tan gelecek izahı beklerdi.

Abdullah b. Mes'ûd da (ö. 32/652-53) kişinin bir konuda bilgisi varsa söylemesini eğer bilmiyorsa çekinmeden "Allah daha iyi bilir." demesini tavsiye etmiştir. İbn Mes'ûd, Sâd sûresinde geçen "Sizden bir ücret istemiyorum. Ben tekellüf sahibi değilim." ayetindeki "tekellüf" ü, bilmediği halde biliyormuş gibi davranma manasında tevil etmiştir. ${ }^{39}$

\footnotetext{
${ }^{36}$ Ebû Osman 'Amr b. Bahr Câhiz,er-Resâilü'l-edebiyye (Beyrut: Mektebetü'l-hilâl, 2004), 200.

${ }^{37}$ el-Bakara $2 / 31$.

38 el-Bakara, 2/32.

${ }^{39}$ İbn 'Abdirabbih, el-'Ikdül-ferîd, 826-831. (Bu kaynakta ilgili hadislerin tahrici yapılmıştır.)
} 
Hz. Ali ise يا بردها على الكبد أن تقول لما لا تعلم: الله أعلم (Bilmediğin konuda "Allah daha iyi bilir demenden daha ferahlatıcı ne olabilir ki?) diyerek "tekellüfe girmeden cevap vermenin huzur vericici tarafına dikkat çekmek-

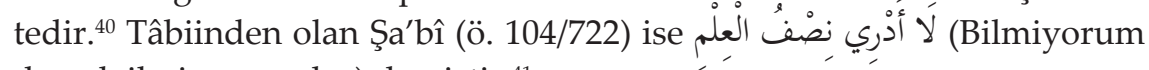
demek ilmin yarısıdır.) demiştir. ${ }^{41}$

\section{SEÇİCI DAVRANMAK VE ÖNCE SUSMAYI ÖĞRENMEK}

İlim talebesinin tahsil hayatı boyunca karşılaşacağı sayısız bilgiler çıkacaktır. Bu bilgilerin hepsine vakıf olmanın imkânsızlı̆̆ını izah etmeye dahi gerek yoktur. O halde ilimle iştigal eden marifet yolcusunun yapacağ1 şey, en başta bu bilgiler hakkında "seçici" davranmasını bilmesidir. Zira ilim meydanı olabildiğince geniş ve gidilebilecek yollar da sayılamayacak kadar çoktur. İbn Abbâs'ın (ö. 68/687-88) dediği gibi hesabı tutulamayacak kadar bilgi vardır. Burada "seçici" davranmanın lüzumu tebarüz etmektedir. Bu yüzden bazı âlimler "Kişinin seçimi aklının yarısıdır." demiştir. Ayrıca ünlü nahivci Halil b. Ahmed (ö. 175/791) ise; "İyi seçim ancak kişinin neye ihtiyacı olmadığın bilmesiyle olur." diyerek ilim talebesinin her şeyden önce neye ihtiyacı olduğunu ya da olmadığını tayin etmesinin önemine işaret etmiştir. ${ }^{42}$ İlim tahsilinde deyim yerinde ise "kuluçlama öncesi" olarak adlandırabileceğimiz bu dönemde ilim talebesine yakışan en güzel ahlaklardan birisi de uygun tercih yapabilmesi için susmasını öğrenmesidir. Zira bu dönem henüz nelerin öğrenilip nelerin sonraya b1rakılacağına dair araştırma safhasıdır. Bu aşamada ilim taliplisi bu yolda kendinden önceki yolcuların tecrübelerine danışmalı ve kendi görüşünü ortaya koymaya çalışmamalıdır. Zamanı geldikçe meselelere vukûfiyeti artıkça zaten fitri olarak güzel sorular soracaktır. Burada susma ile ilgili klasik Arap edebiyatında ilgi çekici pasajlara yer vermek yerinde olacaktır.

Arapların divanı olan şiir, Araplığa ait kültürel, dini ve ahlaki her ne varsa içinde barındırmış ve güçlü bir kültürel miras olarak nesilden nesile aktarıla gelmiştir. Bu mirasın içerisindeki ahlaki erdemlerden bir tanesi de gerektiği yerde susmasını bilmektir. Kur'ân ve Sünnet'te övülen bilgece suskunluk, edebin ve vakarın bir gereği olarak görülmüş ve kişinin sosyal itibarının da bir göstergesi olmuştur. Arap şiirinde ilk dönemden itibaren bu anlamlı suskunluk şiire konu olmuştur. Araplar tarafından sosyal ha-

\footnotetext{
${ }^{40}$ Ebû Muhammed ed-Dârimî, Kitâbu '-müsnedi'l-câmi', thk. Nebîl Burhân (Mekke: Dârul'lbeşâiri'l-İslâmiyye, 2013), 137.

${ }^{41}$ Dârimî, Kitâbu'l-müsnedil-câmi', 138.

${ }^{42}$ Veşşâ, ez-Zarf ve'z-zurafâ, thk. Kemâl Mustafâ (Misır: Mektebetu'l-Hâncî, 1953), 2.
} 
yatta ziyadesiyle önem verilen "mürûet/itibar" olgusunun umdelerinden biri olan diline hâkim olmak ve gerektiğinde susmasını bilmek özellikle zühd ve hikmet eğilimli şairlerce işlenmiştir. Bu şairlerden birisi de Arap edebiyatında zühd denildiğine ilk akla gelen isim Ebu'l-Atahiye'dir (ö. 210/825). Ebu'l-Atâhiye'nin şu şiiri susmanın meziyetine dair belki de söylenmiş en güzel sözler arasında yer almaktadır:
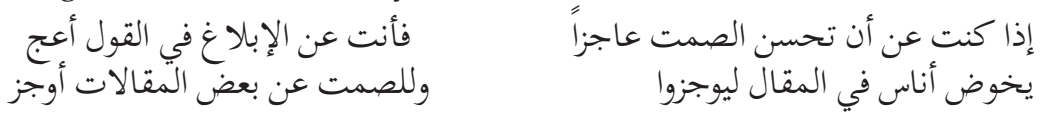

Şayet güzelce susmasın bilmekten aciz isen, sözü güzelce söylemekten daha acizsindir.

İnsanlar veciz söz söylemeye kalkışırlar; hâlbuki bazı sözlerde susmak en veciz olanidir. ${ }^{43}$

Ebu'l- Atâhiye, içinden gelen konuşma isteğini susma iradesiyle durdurmaktan aciz olan kişinin, konuştuğu zaman güzelce meramın anlatmaktan daha da aciz olacağını ifade etmektedir. O halde konuşma maksadını zihninde iyice tasarlayı israf-ı kelama girmeden beyanda bulunabilmenin ön koşulu "susma iradesi" gösterebilmektir. O halde Ebu'l-Âtâhiye'ye göre susma iradesi "güzel konuşma" sanatından daha da öncelikli olmalıdır. Diğer beyitte ise şair bazı kimselerin edebiyatçı havasına girerek "veciz" sözler söylemeye çalışmasını iğneli bir üslupla tenkit etmektedir. Hâlbuki böyle kimseler için en veciz ifade biçimi susmak olmalıdır. Maksadını en veciz bir şekilde dile getirmek için tekellüfe giren kimselerin her şeyden evvel susmasını öğrenmesi evladır. Hatta değil kendi düşüncesini ifade etmesi, başka birinden duyduğu bir sözü aktarırken de kişi sözü olduğu gibi aktarabilme gayretinde olmalı hatta söylenen sözden emin değilse o anda da susmasını bilmelidir. Zira ünlü Arap şairi Ebu'l-Maarrî'nin de dediği gibi:

$$
\text { والنقل غير أنباء سمعت بها وآفة القول تقليل وتكثير }
$$

"Ve aktarım, duyduğun şeyleri hep değiştirmiştir. Sözün afeti ise azaltma ve çoğaltmadır." ${ }^{\prime 4}$

Hafızasının güçlülüğü ile bilinen el-Maarrî' nin dikkat çekmek istediği konu gayet hassastır. Zira çoğu kez kaynağından çıan söz kulaklara ulaşıncaya kadar biçim ve içerik bakımından epey bir aslından uzaklaşmaktadır. O halde ilim talebesinin başkalarına ait düşünceleri aktarırken de yapması doğru olan şey sözün aslını tam olarak tespit ve tahkik edinceye kadar yine susmasını bilmesidir.

${ }^{43}$ Veşşâ, ez-Zarf ve'z-zurafâ, 6.

${ }^{44}$ Ahmed Kubeş, Mecmau'l-hikem ve't-emsâl fi'ş-şi'rit-Arabî (Şam: Dâru'n-neşr, 1985), 292. 
Susma adabı üzerine pek çok şiir ve hikemi sözler söylenmiş hatta müstakil eserler dahi kaleme alınmıştır. Ahlaki erdemler ve zühd üzerine eserlerinin çokluğu ile bilinen âlimlerden birisi de İbn Ebü'd-Dünyâ'dır. Müellif, Kitâbu's-samt ve âdâbu'-lisân adlı eserinde susma sanatı hakkındaki literatürü bir araya getirmiştir. Bu eserde Müslümanca konuşma üzerine söylenmiş pek çok hadis ve kavil bulunmaktadır. Hadislerde yer alan "Dilini tutana ne mutlu!"46; ما شيء أحق بطول سجن من اللسان "Dilden daha çok hapsedilmeye hak eden bir şey yoktur." ${ }^{\prime 7}$ vb. cevamiu'l-kelim kabilinden ifadeler, susmaya dair akılda kalıcı veciz uyarılardır. Bunun dışında eserde azımsanmayacak sayıda şiir pasajları da yer almaktadır. Eserde el-A'var eş-Şenîyy'ye nispet edilen şu beyit insanı insan yapan değerin asıl dil ve gönül olduğunu vurgulamaktadir:

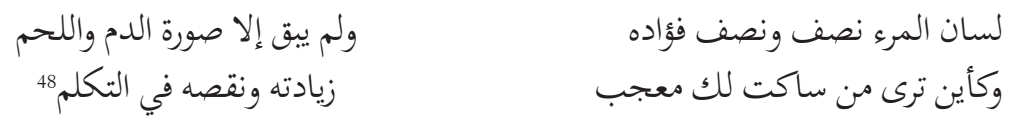

Kişinin lisanı onun yarısıdır; diğer yarısı da kalbi.

Bundan başka da sadece et ve kandan ibarettir.

Nice sessiz kimseleri görürsün; hoşuna gider.

Onun gözünde büyümesi ve küçülmesi onun konuşmasındadır. ${ }^{49}$

Mevlâna Celaleddîn Rûmi'nin “Ey Birader! Sen ancak endişesin, o düşünceden ibaretsin, geri kalan şeyin, kemik ve deriden başka bir şey değildir." sözünü hatırlatan bu şiire göre insan olmak bir süreçtir. ${ }^{50}$ Ömür boyu devam edecek bir tekâmül yolculuğu olan "insan oluş", iki şairin de vurguladığı gibi "et, kan ve kemik" in ötesinde, başka boyutlarda cereyan

${ }^{45}$ İbn Ebü'd-Dünyâ, Ebû Bekr Abdullah b. Muhammed b. Ubeyd,Kitâbu's-samt ve âdâbu llisân, thk. Ebû İshâk el-Huveyni (Beyrut: Dâru'1-kitâbi'l-Arabî, 1990), 49.

${ }^{46}$ İbn Ebü'd-Dünyâ, Kitâbu's-samt ve âdâbu'-lisân, 53.

47 İbn Ebü'd-Dünyâ, Kitâbu's-samt ve âdâbu'-lisân, 57.

${ }^{48}$ Şairin iki beytinin sıralamasının ve bazı kelimelerinin, Seyyid Ziyâuddin el-Hayderî tarafından tahkiki yapılan şaire ait divanında farklı olduğu görülmüştür. Divandaki iki beyit şöyledir:

زيادته ونقصه في التكلم وكأن ترى من صامت لك معجب الكب

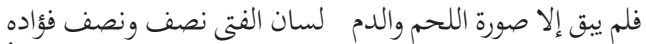

İlgili ayrıntı için bk. el-A'var eş-Şeniyy, Dîvân, tah. Seyyid Ziyâuddin el-Hayderî, (Beyrut: Dâru'l-mevâhib, 1999), 39.

49 İbn Ebü'd-Dünyâ, Kitâbu's-samt ve âdâbu't-lisân, 72.

${ }^{50}$ Benzer yaklaşımı geçen yüzyılın varoluşçu felsefecilerinden Gabriel Marcel'de de (ö. 1973) görmek mümkündür. Marcel'e göre; insan olmuş, tamamlanmış bir ürün olmayıp oluş halindeki bir varlıktır. Emel Koç, "Bir Umut Metafiziği Olarak Gabriel Marcel Felsefesi", Süleyman Demirel Üniversitesi Fen Edebiyat Fakültesi Sosyal Bilimler Dergisi 18 (Aralık 2008), 171-194. 
etmektedir. Ebü'd-Dünyâ bu tekâmülü dil ve kalpte görmüş, yükseliş ve alçalışın göstergesi olarak da kişinin kelamını nazara vermiştir.

Burada "susma" hususunda ölçüyü kaçırmama adına bir hatırlatmada bulunmak gerekmektedir. Zira ne susma ne de konuşma mutlak surette yerilecek ya da övülecek şeylerdir. Hemen hemen her ahlaki tutum ve davranışta olduğu gibi bunların da fazilet sayılacağı "bir yeri" olmalıdır. Daha açıç̧a söylemek gerekirse yerine göre konuşmak ve yerine göre susmak elzemdir. Şair Nâbî'nin (ö. 1712) Olma mecliste ne bir güne hâmûşvakt ile gâh zehân ol gehgûş̧ (Mecliste tekdüze durup susma; yeri geldikçe dil ol, yeri geldikçe kulak) ${ }^{51}$ dediği gibi vasat çizgiye riayet etmelidir. Zira meşhur Arap edebiyatçısı Câhız'ın da (ö. 255/869) dediği gibi susmanın erdem olduğu yerler "hâss" iken konuşmanin fazileti "hâss" ve "âmm"dır. ${ }^{52}$ Yani sosyal ilişkilerimizde ve hayatın doğal akışı içinde genel olan "konuşmak" iken bazı hususi durumlarda "susmak" en doğru olanıdır. Bu, hem dünyevi hem de uhrevi hayatımızın selameti açısından bir dengeyi zorunlu kılmaktadır. Konuşma ve susma arasındaki dengeyi sağlayabileceğimiz terazi "vicdan"larda kuruludur. Dolayısıyla ne ölçüde ve hangi zamanlarda susulması ve konuşulması gerektiği hususlarında her ne kadar "edeb/âdâb" literatürümüz zengin olsa da bunu uygulatacak olan nihayetinde vicdanımızdır; ortamın gerektirdiği en uygun davranışı kulağımıza fısıldayacak olan yine ferasetimizdir.

\section{TUZAK NIYYETLİ SORULARDAN SAKINMAK}

İlim tahsilinde karşılaşılan sorunlardan birisi de talebenin kimi zaman karmaşık meselelerle muhatap olmasıdır. Kimi zaman bu tür konular talebenin ilgi ve merakını cezbederek öğrenmeye olan şevkini artırsa da çoğu zaman aklını karıştırıp ilimle iştigale karşı bir soğukluk ve moral bozukluğu vermektedir. İnsan doğası gereği bilmediği şeye düşman olmakta ve anlayabildiği konulara meyletmektedir. Burada ihtiyaç halinde güzelce soru sormanın ehemmiyeti ortaya çıkmaktadır. Zira İbn Ömer'den nak-

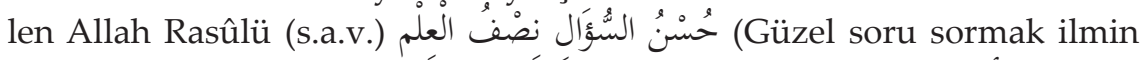
حسن المسألة نصف(ôn “Güzel soru sormak anlayışın yarısıdır.” demiştir. Zeyd b. Eslem (ö. 136/754) kendisine sorulan bir soru karşısında "Sen önce soru sormasını

${ }^{51}$ Nurullah Aydeniz, Şair Nâbı̂'den Öğütler, (Hayriyye Üzerine Bir Değerlendirme) (İstanbul: Hiperlink Yayınları, 2018), 102.

${ }^{52}$ Câhiz, Raseil'ul-Câhız, thk. Abdüsselâm Muhammed Hârûn (Beyrût: Dâru'l-cîl, ts.), 4/233.

${ }^{53}$ Abdülhatîb Tebrîzî, Şerhu mişkâti'l-misbâh, thk. Cemâl Aytânî (Beyrut: Dâru'l-kutubi'lilmiyye, 2001), 9/264. 
öğren, sonra gel sor." diyerek soru sormanın da bir adabı olduğunu hatırlatmıştır. ${ }^{54}$ Ilk dönem İslam bilginlerinden İbn Kuteybe (ö. 276/889) “ilim ve beyan"a tahsis ettiği kitabında yer verdiği ilk hadisin bu konuya ayrılması dikkatimizi çekmiştir. Muâviye b. Ebî Süfyân'ın (ö. 60/680) naklettiğine göre Hz. Peygamber (s.a.v.) "الأغلوطات" denilen şeylerden sakındırmıştır. Sözlükte safsata anlamına gelen ve Türkçemizde de kök itibariyle "mugalata" olarak kullanılan bu kelimeye Evzâî, (ö. 157/774) "صعاب المسائل " "صائل "yani "zor sorular" ya da "karmaşık meseleler" anlamını vermiştir. ${ }^{55}$ Bu hadiste geçen الأغلوطات kelimesinin şerhine dair muhaddisler benzer yorumlarda bulunmuşlardır. Bu yorumlara bütün halinde bakmak hadisten kastedilen manayı anlamaya dair faydalı olacaktır.

Bağavî'nin (ö. 516/1122) Mesâbîhus's-Sünne'si üzerine şerh yazan Kâdî

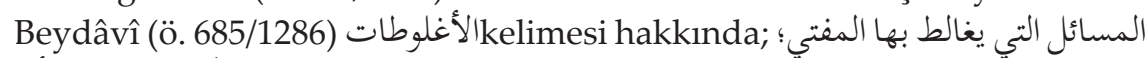
şeklinde izahta bulunmuştur. Hadiste yasaklanan kendisinden fetva istenilen kimsenin kafasını karıştırmak ve onun düşüncesini iskat etmek için sorulan sorular" dır. ${ }^{56}$

Alî el-Kârî (ö. 1014/1605) ise Hz. Peygamber'in (s.a.v.) yasakladığ1 içerikli "tuzak sorular" In mahiyetine ilişkin bir yorumda bulunmaktadır. İçeriği itibariyle soruya muhatap olan kişiyi zor durumda bırakıp soranın üstünlügünü gösterecek sorularla âlimleri ters köşe etme niyeti, tamamen الأغلوطات kapsamındadır. Hatta soru soran kişinin niyeti sadece ve sadece soru sorulan kişiye "eza vermek" ise bunun "haram" olduğu ifade edilmiştir. Zira burada soru soran kişinin niyeti "eza"dır. Hâlbuki mümine eziyet vermekten âyetler açıcça sakındırmaktadır. ${ }^{57}$ Diğer taraftan böyle bir niyet sahibi "fitne ve düşmanlık" kışkırtacak şekilde tahrikkâr davranış göstermektedir. Şarihe göre perde arkasında "fitne, düşmanlık, eziyet, büyüklük taslamak" gibi kötü ahlakları barındıran bir sorgu şekli hakikaten de "haram" olmalıdır. ${ }^{58}$

Hattâbî (ö. 388/998) ise الأغلوطات hakkındaki hadisin, insanın sormaya ihtiyacı olmadığı meselelerde derinleşmeye ve tekellüfe girmesinin kerahetini ifade ettiğini belirtmiştir. Sorulacak kişide eğer söz konusu ilmin bulunmadığı hissedilirse soru sormaktan sakınmak gerekir. Übeyy b. Ka'b’a

\footnotetext{
${ }^{54}$ Hatîb el-Bağdâdî, el-Câmi' liahlâki'r-râvî ve âdâbi's-sâmi', thk. Mahmûd ed-Tahhân (Riyâd: Mektebetu'l-maârif, 1983), 213.

${ }_{55}$ İbn Kuteybe, Kitâbu uyûni'-ahbâr, 2/117.

${ }^{56}$ Kâdî Beydâvî, Tuhfetu'l-ebrâr şerhu mesâbihi's-Sünne, thk. Nureddîn Tâlib (Kuveyt: Vizâratu'l-evkâf, 2012), 1/162.

57 İlgili âyetler için bk. el-Ahzâb 33/58, el-Mâide 5/2.

${ }^{58}$ Ebü'l-Hasen Nûrüddîn Alî b. Sultân Muhammed el-Kārî el-Herevî, Mirkâtu'l-mefâtîh şerhu mişkâti'l-mesâbîh, (Beyrut: Dâru'l-fikr, 2002), 1/319.
} 
(ö. 33/654) bir adam gelerek muğlak şeyler hakkında sorular sormuştur. $\mathrm{Ka}^{\prime} \mathrm{b}$ ise cevap vermeye çalışmak yerine bu sorduğu şeylerin olup olmadığını sormuş ve hayır cevabı alınca o zaman olduğu zaman görüşürüz demiştir. Yine başka bir adam Mâlik b. Enes'e gelerek bir adamın namaz esnasında unutarak bir şey içerse hükmünün ne olduğunu sormuştur. Kişinin namazda olduğunu unutarak bir şeyler içmesinin son derece düşük bir ihtimal olduğunu ve dolayısıyla da bu türden bir soruyla yapay bir sorun üretmenin anlamsızlığını kastederek "Neden zehir içmedi?" demiş ve üstü kapalı bir üslupla şahsı kınamıştır. ${ }^{59}$

Sadece bir şeyler öğrenmek maksadı dışında garazkâr sorular sormanın çirkin bir davranış olduğunu belirten başka mealde hadisler de vardır. Süyûtî'nin (ö. 911/1505) Câmiu's-Sagîr adlı eserinde geçen bir hadis ve San'ânî'nin (ö. 1182/1768) bu rivayete yaptı̆̆ şerh "soru soranların niyeti"

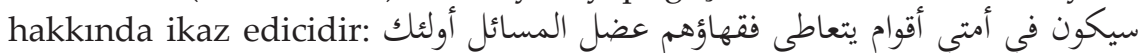
"Ümmetim içinde fakihleri muğlak meseleleri ele alan kavimler çıkacak. Bunlar benim ümmetimin en şerli olanlarıdır."

Zor meseleler olarak çevirdiğimiz عضل المسائل ibaresinin şerhe muhtaç bir ifade olduğu açıktır. Zira öyle konular vardır ki kimine göre gayet kolayken o meselede edna bir vukûfiyeti olmayan kimseler için gerçekten de karmaşık ve muğlaktır. San'ânî hadise getirdiği şerhinde hadisin "kişinin

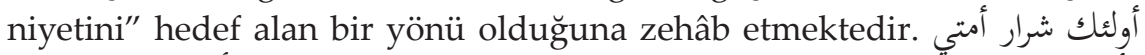

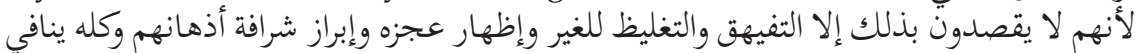
"Onlar ümmetimin en şerli olanlarıdır. Zira onlar; başkalarına kaba davranabilmek, ayrintılara dalabilmek, başkaların aciz bırakmak ve kendi üstünlüklerini göstermek maksadıyla ilimle meşguldürler. Bütün bunlar ise ilim ve talim maksadına münafi şeylerdir." ${ }^{\prime 60}$

Görüldüğg̈ gibi şerh, hadiste geçen عضل المسائل ibaresini kayıtlamaya çalışmaktadır. Zira biraz önce değindiğimiz gibi müzakere edilen meselelerin zorluk/kolaylık keyfiyeti belki de çoğu zaman sübjektif kalmaktadır. Müçtehit imamların ele aldığı konuların neredeyse tamamı ehli olmayan kimseler için عضل المسائل olabilmektedir. O halde hadisin metninde geçen şerli âlimler San'ânî'nin şerh ettiği şekliyle mücerred üstünlük taslamak kastıyla karmaşık konulara girmeyi adet edinmiş ilim ehli olmalıdır. O halde herhangi bir meselede tartışma açan kişiye düşen, niyetini en başta halis tutmaya çalışması ve ilimle dalalete düşen kimseler olmaktan kaygı duymasıdır.

${ }^{59}$ Hattâbî, Meâlimu's-sünen, thk. Muhammed Râgib Dabbâh (Halep: Matbaatu'l-ilmiyye, 1934), 4/186.

${ }^{60}$ Emîr es-San'ânî, Kitâbu't-tenvîr şerhu'-câmii's-sagîr, 6/446. 
Yukarıda zikredilen الأغلوطات kelimesine benzer olarak aynı kökten türeyen bir başka kelime, الأغاليط yine İbn Abdilberr'in (ö. 463/1071 Câmiu beyânil-ilmi ve fadlihî adlı eserinde yer almaktadır. Yahyâ b. Eyyûb'e nis-

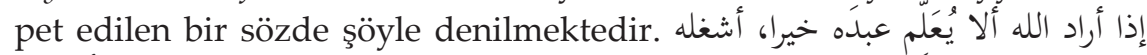
"Allah bir kuluna hayır öğretmek istemezse onu karmaşık meselelerle meşgul eder." ${ }^{161}$

Buraya kadar zikredilen kavillere bir bütün halinde bakıldığında ilim talebesinin ilim öğrenmek için gayretli olması gerektiği gibi diğer başka hususlara da riayet etmesi gereklidir. Neden ilim öğreniyorum sorusuna cevap bulabilmelidir. İlim noktasında kendisine sebkat eden kimselere soru sorma adabından tahsil etmeye niyetlendiği malumatın içeriğine kadar daha pek çok incelik kendisinden dikkatli olmasını gerekli kılmaktadır.

"Bazı kavimler çok soru sorduğu için helak olmuştur."

Gördügüumüz kadarıyla, ilimle iştigal eden kimselerin çokça duyduğu bu sözün hadis kaynaklarında bir karşılığı bulunmaktadır. Buhari'de geçen bir hadiste Hz. Peygamber (s.a.v.) Allah'ın haram kıldığı şeyler arasında كثرة السؤال "çok soru sormak"1 zikretmiştir. ${ }^{62}$

Muzhiruddîn Zeydâni (ö. 767/1366) bu hadisin şerhinde; kastedilenin âlimlerden ihtiyaç olmayan konularda معارضة (inatlaşma ve muhalefet etme) maksatlı soru sorma olduğunu belirtmiştir. Yoksa ihtiyaç olan konularda soru sormanın müstahsen bir iş olduğunu ve bunda da bir ecir beklenilebileceğini ifade etmiştir. İlim öğrenme maksadıyla soru sormanın mekruh değil bilakis müstehab olduğunu vurgulamıştır. ${ }^{63}$ Diğer bir كثرة السؤال عن خئ İnsanların haberleri ve zamanın olaylar hakkında çok soru sormak) ile alakalı olabileceğini söylemiştir. Zira bu tür sorularda dinde açıkça yasaklanan "dedikodu" ya yaklaşma riski bulunmaktadır. ${ }^{64}$

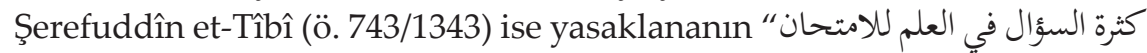
"Karşısındakini sınamak ve münakaşa çıkarmak için çok soru sormak) olabileceğini düşünmüştür. ${ }^{65}$ İmam Nevevî (ö. 676/1277) ise ko-

\footnotetext{
${ }^{61}$ İbnu Abdi'l-berr, Câmiu beyâni'l-ilmi ve fadlihî, 1078.

${ }^{62}$ Ebû Abdillâh Muhammed b. İsmail el-Buhârî, el-Câmi' u'ș-șahîh, nşr. Muhammed Züheyr b. Nasr (b.y.: Dâru Tavki'n-Necât, 1422/2001), "el-I'"isâm", 96 (No. 7292).

${ }^{63}$ Muzhiruddîn Zeydâni, el-Mefâtîh fì şerhi'-mesâbîh, thk. Nureddîn Tâlib (b.y. İdâratu'ssekâfeti'l-İslâmiyye, 2012), 5/203.

${ }^{64}$ Kâdî İyâz, İken-mâlu'l-muallim bifevâid-i Muslim, thk. Yahyâ İsmâîl (el-Mansûra: Dâru'l-vefâ, 1998), 5/569.

${ }^{65}$ Şerefuddîn et-Tîbî, el-Kâşif an hakâiki's-Sünen, thk. Abdülhamîd Hindâvi (Mekke: Mektebetu Nizâr Mustafa el-Bâz, 1998), 10/3158.
} 
nuyla ilgili şerhinde والإكثار عن السؤال عما لا يقعdiyerek hadisin yasakladığ1 hususun henüz vuku bulmamış farazi şeyler üzerinden soru sormaya dair olabileceğini ifade etmiştir. ${ }^{66}$ Bu yorum ise daha önce Übeyy $b$. Ka' $b^{\prime} ı n$ verdiği "Olursa düşünürüz." cevabındaki yaklaşımına benzemektedir. Burada Nevevî'nin hadiste yasaklanan hususu "henüz vuku bulmamış" şeyler üzerine soru sorma ile yorumlaması önemlidir. Zira kimi zaman ilim talebesi belki kötü niyetle de değil, farkında bile olmadan zihninde beliren imgeler üzerinden olası sorunlar üretebilmektedir. "Şöyle ya da böyle olursa nasıl olur? Ne demek lazım?" gibi o anlık vücuda gelmemiş şeylere dair cevaplar aramak hikmetli bir davranış olmasa gerektir. Zira bu tarzda farazi meseleler üzerine sınırlandırma yapmak mümkün değildir ve hayalin bu bakımdan nerede duracağı da meçhuldür. Dolayısıyla kişinin lüzumlu meselelere sarf etmesi gerektiği akli melekesini hayalin peşine takarak şimdilik varlığı bile bulunmayan konulara dalması, çözümler araması söz konusu hadisin sakındırdığı bir konu olması mümkündür. Bu yoruma göre hoş karşılanmayan durum, sorulan sorunun içeriğinden ziyade taalluk ettiği şeyle ilgilidir. Nitekim kişiyi ilgilendirmeyen hususların peşine düşmemesi ve araştırmaması ile ilgili epey bir sakındırma zaten mevcuttur. "Bilginin olmadiğı şeyin peşine düşme." ${ }^{67}$ âyeti ve "Kişinin kendisini ilgilendirmeyen şeyi terk etmesi onun İslamiyet'inin güzelliğindendir." hadisi ${ }^{68}$ üzerinde durduğumuz konunun daha geniş bir çerçevesini çizmektedir.

\section{SONUÇ}

Şiir, nesir ve hadis türü Arap edebiyatı kaynaklarından hareketle ilmin önemi ve ilim tahsilinde yol almak isteyen talebe açısından ilim yolculuğu esnasındaki kilometre taşlarına dair bu çalışmada, erken dönem edebi metinler taranmış ve günümüz İslami ilimler öğrencilerine yönelik olacak şekilde yorumlanmıştır. Daha ziyade erken dönem Arap edebiyatçılarının ilim tahsiline yönelik tavsiye ve değerlendirmelerine yer verilmiş ve ilim konulu hadis şerhleri belirli bağlamlar çerçevesinde anlam bütünlüğü oluşturacak şekilde derlenmiştir. Bu metinler üzerinden meseleye bakıld1ğında genel olarak ilimle meşgul olmak isteyen talebenin en baştan itibaren hayatı boyunca ilme karşı niyetini samimi tutması ve ilimden maksadın ne olduğu hususunda hep müteyakkız bulunmasının altı çizilmiştir.

${ }^{66}$ Ebû Zekeriyya en-Nevevî, Sahîh-i Muslim bişerhi'n-Nevevî (Mısır: el-Matbaatu'l-Mısriyye bi'l-Ezher, 1930), 12/11.

${ }^{67}$ el-İsrâ $17 / 36$.

${ }^{68}$ Ahmed b. Hanbel, Müsned, 3/259. 


\section{KAYNAKÇA}

Ahmed b. Hanbel. Müsnedü'l-İmam Ahmed b. Hanbel. thk. Şu'ayb el-Arnâût. 50 Cilt. Beyrut: Müessesetü'r-Risâle, 2001.

Alî el-Kārî, Ebü'l-Hasen Nûrüddîn b. Sultân Muhammed el-Herevî. Mirkâtu'lmefâtîh şerhu mişkâti'l-mesâbîh. Beyrut: Dâru'l-fikr, 2002.

Aydeniz, Nurullah. Şair Nâbî'den Öğ̈ütler. (Hayriyye Üzerine Bir Değerlendirme). İstanbul: Hiperlink Yayınları, 2018.

Bağdâdî, Hatîb. el-Câmi' liahlâki'r-râvî ve âdâbi's-sâmi'. thk. Mahmûd ed-Tahhân. 2 Cilt. Riyâd: Mektebetu'l-maârif, 1983.

Bilgegil, M. Kaya. Edebiyat Bilgi ve Teorileri. Erzurum: Salkımsöğüt Yayınevi, 2015.

Buhârî, Ebû Abdillah Muhammed b. İsmâil. Sahîhu'l-Buhârî. thk. Muhammed Zuheyr b. Nâsirinnâsir. 9 Cilt. Dârü'tavki'n-necât. 1422/2001.

Câhiz, Ebû Osman 'Amr b. Bahr. er-Resâilül-edebiyye. Beyrut: Mektebetü'l-hilâl, 2004.

Câhiz, Ebû Osman 'Amr b. Bahr. Kitâbü'l-mehâsin ve'l-azdâd. Beyrut: Mektebetü'lHilâl, 2004.

Câhiz, Ebû Osmân Amr b. Bahr b. Mahbûb. Raseil'ul-Câhız. thk. Abdüsselâm Muhammed Hârûn. 4 Cilt. Beyrût: Dâru'l-cîl, ts.

Cürcânî, Ali b. Muhammed Seyyid Şerîf. Kitâbü't-Ta'rîfât. thk. Heyet. Beyrut: Dârü'l-kütübi'l-'ilmiyye, 1983.

Dârimî, Ebû Muhammed. Kitâbu'l-müsnedil-câmi'. thk. Nebîl Burhân. Mekke: Dârul'l-beşâiri'l-İslâmiyye, 2013.

Hattâbî, EbûSüleymânHamd (Ahmed) b. Muhammed b. İbrâhîm b. Hattâb. Meâlimu's-sünen. thk. Muhammed RâgibDabbâh. Halep: Matbaatu'lilmiyye, 1934.

İbn 'Abdirabbih, Ebû Ömer Şihâbüddîn Ahmed b. Muhammed b. Abdirabbih b. Habîb. el-'Ikdül-ferîd. thk. Müfîd Muhammed Kumeyha. 8 Cilt. Beyrut:Dârü'l-kütübi'l-ilmiyye, 1983.

İbn Ebü'd-Dünyâ, Ebû Bekr Abdullah b. Muhammed b. Ubeyd. Kitâbu's-samt ve âdâbu'l-lisân.thk. Ebû İshâk el-Huveyni. Beyrut: Dâru'l-kitâbi'l-Arabî, 1990.

İbn Kuteybe, Ebû Muhammed Abdullâh b. Müslim. 'Uyûnu'l-ahbâr. 4 Cilt. Beyrut: Dâru'l-kütübi'l-ilmiyye, 1997.

İbnu Abdi'lberr, Ebû Ömer CemâlüddînYûsuf b. Abdillâh b. Muhammed b. Abdilberr en-Nemerî, Câmiu beyâni'l-ilmi ve fadlihî. thk. Ebu'l-Eşbâl ez-Zuheyrî. 2 Cilt. Riyâd: Dâruİbni'l-Cevzî, 1994.

Kâdî Beydâvî. Tuhfetu'l-ebrâr şerhu mesâbihi's-Sünne. thk. NureddînTâlib. 3 Cilt. Kuveyt: Vizâratu'l-evkâf, 2012. 
Kâdî İyâz. İkmâlu'-muallim bifevâid-i Muslim. thk. Yahyâİsmâîl. el-Mansûra. 8 Cilt. Mısır: Dâru'l-vefâ, 1998.

Koç, Emel. "Bir Umut Metafiziği Olarak Gabriel Marcel Felsefesi”. Süleyman Demirel Üniversitesi Fen Edebiyat Fakültesi Sosyal Bilimler Dergisi 18 (Aralık 2008): 171-194.

Kubeş, Ahmed. Mecmau'l-hikem ve'l-emsâl fi'ş-şi'ri'l-Arabî. Dimeşk: Dâru'n-neşr, 1985.

Nevevî, Ebû Zekeriyyâ Yahyâ b. Şeref b. Mürî. Sahîh-i Muslim bişerhi'n-Nevevî. 18 Cilt. Misır: el-Matbaatu'l-Misriyye bi'l-Ezher, 1930.

Râgıp el-İsfehânî, Ebü'l-KāsımHüseyn b. Muhammed b. el-Mufaddal. el-Müfredât fì garîbi'l-Ku'rân. thk. Saffân Adnân ed-Dâvûdî. Dimeşk: Dârü'l-kalem, 1991.

Râgıp el-İsfehânî, Ebü'l-Kāsım Hüseyn b. Muhammed b. el-Mufaddal. Muhâdarâtü'lüdebâ. 2 Cilt. Beyrut: Dârü'l-Erkam b. Ebi'l-Erkam,1999.

Se'âlibî, Ebû Mansûr. eş-Şekvâ ve'l-itâb ve mavaka'abeyne'l-hillân vel-eshâb. thk. İlhâmAbdülfettah el-Müftî. Kuveyt: el-Meclisü'l-vatanî li's-sekâfe ve'1fünûn, 2000.

Şâfiî, Muhammed b. İdrîs. Dîvânu I-İmâmi'ş-Şâfiî. nşr. Muhammed İbrâhîm Selîm. Kahire: Mektebetu İbn Sînâ, ts.

Şeniyy el-A'var. Dîvân. thk.Seyyid Ziyâuddin el-Hayderî. Beyrut: Dâru'l-mevâhib, 1999.

Tebrîzî, Abdülhatîb. Şerhu mişkâti'l-misbâh, thk. Cemâl Aytânî. 2 Cilt. Beyrut: Dâru'l-kutubi'l-ilmiyye, 2001.

Tevhîdî, EbûHayyân el-Endelusî. el-Basâir ve'z-zehâir. thk. Vedâd el-Kâdî. 10 Cilt. Beyrut: DârüSâdir, 1988.

Tîbî, Şerefuddîn. el-Kâşif an hakâiki's-Sünen. thk. Abdülhamîd Hindâvi. 13 Cilt. Mekke: Mektebetu Nizâr Mustafa el-Bâz, 1998.

Veşşâ, Ebü't-Tayyib Muhammed b. Ahmed b. İshâk b. Yahyâ.ez-Zarf ve'z-zurafâ. thk. Kemâl Mustafâ. Misır: Mektebetu'l-Hâncî, 1953.

Zemahşerî, Ebü'l-Kāsım Mahmûd b. Ömer b. Muhammed el-Hârizmî. el-Keşşâf an hakâiki ğavâmidi't-tenzil. 4 Cilt. Beyrut: Dâru'l-kitâbi'l-arabî, 1987.

Zeydâni, Muzhiruddîn. el-Mefâtîh fî şerhi'l-mesâbîh. thk. Nureddîn Tâlib. 6 Cilt. Kuveyt: İdâratu's-sekâfeti'l-İslâmiyye, 2012. 